\title{
Polish experience in the area of management of the waste generated during the exploration for hydrocarbons from unconventional accumulations
}

\author{
Justyna Pyssa1,a \\ ${ }^{1}$ AGH University of Science and Technology, Faculty of Energy and Fuel, Al. Mickiewicza 30, 30-059 Cracow, Poland
}

\begin{abstract}
The work presents the status of works over the gas exploration from unconventional accumulations in Poland as of the $4^{\text {th }}$ of January 2016. Both the qualitative and quantitative characteristics of waste generated during the exploration for hydrocarbons from unconventional accumulations (data for the years 2010-2014) are presented in the paper. Due to the high content of water and the consistency of waste as well as its changeable and hard-to-predict chemical composition, the waste is difficult to manage. Possible manners of the management of drilling waste connected with the exploration and exploitation of hydrocarbons from unconventional accumulations in Poland and logistical challenges related to it are also discussed in the paper.
\end{abstract}

\section{Introduction}

The first borehole in Poland aimed at the exploration for natural gas from shales was drilled in the year 2010 . The drilling waste is generated at all stages related to the exploration and exploitation of hydrocarbons from unconventional accumulations.

The natural gas from shale accumulations is released through drilling holes reaching the depth of several thousand meters. In order to cause the flow of gas into the borehole, operations of hydraulic fracturing in a number from several to over a dozen are executed in horizontal sections. The result is the generation of a considerable amount of waste. Managing that waste poses a logistical, technological as well as environmental problem.

To the main sources of pollution residing in the drilling waste one can classify chemical agents used for drilling fluid composition, biocides, oil-derived substances, corrosion inhibitors, and reservoir fluids in a form of brine and crude oil.

\section{Area of exploration in Poland}

The exploration for and release of unconventional accumulations of natural gas, contained predominantly in oil-bearing black argillaceous and mudstone shale rocks originating from Silurian and Devonian as well as trapped in sandstones of the Rotliegend, is performed mostly through horizontal bores. The reason behind is obtaining a network of artificial crevices resulting from hydraulic fracturing over a large area of the deposit [1]. Till the $1^{\text {st }}$ of February 201672 boreholes for the exploration were

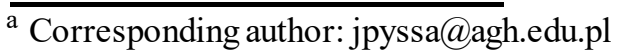

drilled in Poland. 25 operations of fracturing were performed in the boreholes, in that 13 treatments were taken in vertical boreholes and 12 in crooked-vertical ones [2]. The table 1 presents the breakdown of finished shale gas exploratory boreholes along with the type of performed special treatments.

Table 1. The breakdown of finished shale gas exploratory boreholes along with the type of performed special treatments [2].

\begin{tabular}{|c|c|c|c|}
\hline $\begin{array}{c}\text { Type of } \\
\text { treatment } \\
\text { performed in } \\
\text { borehole }\end{array}$ & $\begin{array}{c}\text { Number of } \\
\text { vertical } \\
\text { boreholes }\end{array}$ & $\begin{array}{c}\text { Number of } \\
\text { crooked- } \\
\text { vertical } \\
\text { boreholes }\end{array}$ & Total \\
\hline Fracturing & 13 & 12 & 25 \\
\hline $\begin{array}{c}\text { Micro- } \\
\text { fracturing/ } \\
\text { Diagnostic } \\
\text { Fracture } \\
\text { Injection Test } \\
\text { (DFIT) }\end{array}$ & 4 & 0 & 4 \\
\hline $\begin{array}{c}\text { No fracturing } \\
\text { Total }\end{array}$ & 37 & 6 & 43 \\
\hline
\end{tabular}

Locations of Polish deposits range from the middleeast Baltic coast through central Poland to the Lubelskie region. Four boreholes were additionally drilled in the south-west part of Poland (in the Silesian Lowland and the Opole region). The figure 1 shows areas of exploration for shale gas (the condition as of the $4^{\text {th }}$ of January 2016). Green points mark the boreholes which 
are finished. The red colour indicates areas where concessions for the exploration for shale gas are in force and the pink one marks places where requests for concessions for the exploration of natural gas have already been submitted.

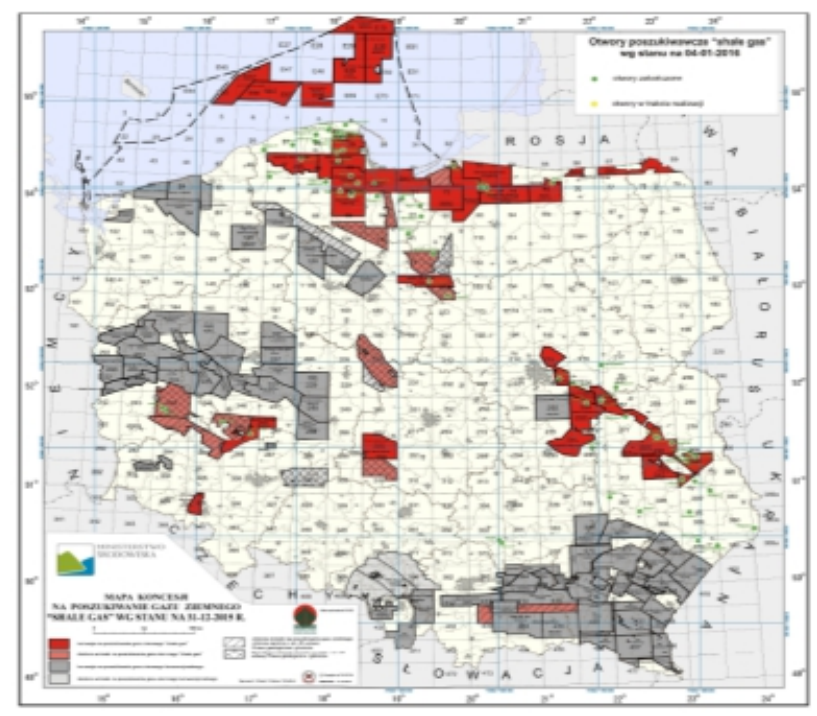

Figure 1. Areas of exploration for shale gas [3].

\section{Applied drilling fluids}

At the time of drilling a borehole, two or three types of water-dispersing drilling fluids are most often used, depending on the depth and drilled layers. For vertical sections and borehole-completion - these are bentonite and polymeric-and-potassium drilling fluids the properties of which can limit the hydration of rocks and they can also be characterized with inhibitive properties $[1,4]$. A typical fracturing fluid contains 95 to 99 percent of volume of water, 3 to 4.5 percent of proppants - used for propping emerging crevices, and 0.5 to 2 percent of chemical additives [5-8]. The composition of such additives may vary depending on the applied technology of extraction and the characteristics of the deposit $[5,8]$. The detailed composition of fracturing fluid used for particular boreholes in Poland is placed on the website of The Polish Exploration and Production Industry Organization [9]. The table 2 presents chemical components which are present in fracturing liquids along with their short characteristics.

\section{Waste generated during exploitation}

As a result of works connected with the exploration and recognition of deposits of natural gas from unconventional accumulations 2 sorts of waste are generated $[4,12,13]$ :

1. Waste connected with drilling works - so-called extractive and drilling waste. Here one can classify used drilling fluids, flow-back fluids, reservoir fluids and solid waste produced during the purification of flow-back fluid (the sludge from separators and reservoirs, flow-back proppant etc.);
2. Waste resulting from the functioning of drilling rig (plastics, packages, filters, sorbents, used oil and grease, communal waste, etc.).

Table 2. Common chemical additives from hydraulic fracturing $[6,7,10,11]$

\begin{tabular}{|c|c|c|c|}
\hline $\begin{array}{c}\text { Additive } \\
\text { tape }\end{array}$ & $\begin{array}{l}\text { Example } \\
\text { compounds }\end{array}$ & Purpose & $\begin{array}{c}\text { Concentration } \\
{[\%]}\end{array}$ \\
\hline Acid & $\begin{array}{l}\text { Hydrochloric } \\
\text { acid }\end{array}$ & $\begin{array}{l}\text { Clean out the } \\
\text { wellbore, } \\
\text { dissolve } \\
\text { minerals, and } \\
\text { initiate cracks } \\
\text { in rock }\end{array}$ & 0.123 \\
\hline $\begin{array}{l}\text { Friction } \\
\text { reducer }\end{array}$ & $\begin{array}{l}\text { Polyacrylamide, } \\
\text { petroleum } \\
\text { distillate }\end{array}$ & $\begin{array}{c}\text { Minimize } \\
\text { friction } \\
\text { between the } \\
\text { fluid and the } \\
\text { pipe }\end{array}$ & $0.088-0.125$ \\
\hline $\begin{array}{l}\text { Corro- } \\
\text { sion } \\
\text { inhibitor }\end{array}$ & $\begin{array}{l}\text { Isopropanol, } \\
\text { acetaldehyde }\end{array}$ & $\begin{array}{c}\text { Prevent } \\
\text { corrosion of } \\
\text { pipe by diluted } \\
\text { acid }\end{array}$ & 0.002 \\
\hline $\begin{array}{l}\text { Iron } \\
\text { control }\end{array}$ & $\begin{array}{l}\text { Citric acid, } \\
\text { thioglycolic acid }\end{array}$ & $\begin{array}{c}\text { Prevent } \\
\text { precipitation of } \\
\text { metal oxides }\end{array}$ & 0.004 \\
\hline Biocide & $\begin{array}{c}\text { Glutaraldehyde, } \\
\text { 2,2-dibromo-3- } \\
\text { nitrolapropiona } \\
\text { mide (DBNPA) }\end{array}$ & $\begin{array}{c}\text { Bacterial } \\
\text { control }\end{array}$ & 0.001 \\
\hline $\begin{array}{l}\text { Gelling } \\
\text { agent }\end{array}$ & $\begin{array}{l}\text { Guar/xantham } \\
\text { gum or } \\
\text { hydroxyethyl } \\
\text { cellulose }\end{array}$ & $\begin{array}{c}\text { Thicken water } \\
\text { to suspend the } \\
\text { sand }\end{array}$ & 0.056 \\
\hline $\begin{array}{l}\text { Cross- } \\
\text { linker }\end{array}$ & Borate salts & $\begin{array}{c}\text { Maximize fluid } \\
\text { viscosity at } \\
\text { high } \\
\text { temperatures } \\
\end{array}$ & 0.007 \\
\hline Breaker & $\begin{array}{l}\text { Ammonium } \\
\text { persulfate, } \\
\text { magnesium } \\
\text { peroxide } \\
\end{array}$ & $\begin{array}{l}\text { Promote } \\
\text { breakdown of } \\
\text { gel polymers }\end{array}$ & 0.01 \\
\hline $\begin{array}{l}\text { Oxygen } \\
\text { scaven- } \\
\text { ger }\end{array}$ & $\begin{array}{l}\text { Ammonium } \\
\text { bisulfite }\end{array}$ & $\begin{array}{c}\text { Remove } \\
\text { oxygen from } \\
\text { fluid to reduce } \\
\text { pipe corrosion }\end{array}$ & 0.005 \\
\hline $\begin{array}{l}\mathrm{pH} \\
\text { adjust- } \\
\text { ment }\end{array}$ & $\begin{array}{l}\text { Potassium or } \\
\text { sodium } \\
\text { hydroxide or } \\
\text { carbonate }\end{array}$ & $\begin{array}{l}\text { Maintain } \\
\text { effectiveness } \\
\text { of other } \\
\text { compounds } \\
\text { (such as } \\
\text { crosslinker) }\end{array}$ & 0.011 \\
\hline Proppant & $\begin{array}{c}\text { Silica quartz } \\
\text { sand }\end{array}$ & $\begin{array}{c}\text { Keep fractures } \\
\text { open }\end{array}$ & $3-4.5$ \\
\hline $\begin{array}{l}\text { Scale } \\
\text { inhibitor }\end{array}$ & Ethylene glycol & $\begin{array}{c}\text { Reduce } \\
\text { deposition on } \\
\text { pipes } \\
\end{array}$ & 0.043 \\
\hline $\begin{array}{c}\text { Surfac- } \\
\text { tant }\end{array}$ & $\begin{array}{c}\text { Ethanol, } \\
\text { isopropyl } \\
\text { alcohol, 2- } \\
\text { butaxyenthanol }\end{array}$ & $\begin{array}{c}\text { Decrease } \\
\text { surface tension } \\
\text { to allow water } \\
\text { recovery }\end{array}$ & 0.085 \\
\hline
\end{tabular}




\subsection{Flow-back Fluid}

The main mass of waste produced during the process of fracturing is the flow-back fluid which contains small volumes of proppant. The proppant comprises the main part of the dry matter in wastes. After the processes of fracturing are finished, a part of the fracturing liquid returns to the surface (flow-back liquid). The volume of liquids which goes back to the surface depends on local geological conditions. According to the data published in an article [10], in Pennsylvania this volume is in a range from 9 to 53 percent with the average at 10 percent. In China in Sichuan Basin between 15 percent to 80 percent [14]. In Poland in the Pomeranian Basin this value is from 9 to 22 percent, while in the Lublin basin it is from 20.6 to 45 percent [13].

\subsection{Used drilling fluids}

The used drilling fluid along with extracted output becomes the drilling waste when the drill of the borehole has been finished. This waste can be characterized with considerable variation in terms of chemical composition as well as potential harmfulness to the environment. Each drilling fluid has an increased $\mathrm{pH}$ value, increased amounts of undissolved and dissolved solid substances (Total dissolves solids - TDS) [8, 14], surfactants, chloride and sulphate ions and dissolved organic carbon (Total organic carbon - TOC). It also includes small amounts of petroleum-derived hydrocarbons [14,15], heavy metals (such as: arsenic, cadmium, barium, chromium, copper, mercury, nickel, lead, antimony, selenium, zinc, tin, cobalt) $[8,11,14]$ and also trace amounts of radioactive substances which come from shale formations $[1,8]$. The table 3 presents chemical composition of the used drilling fluids.

Table 3. Chemical composition of used drilling fluids [author's own research based on [13].

\begin{tabular}{|l|c|c|}
\hline \multirow{2}{*}{ Ele mental } & Pomeranian Basin & Lublin Basin \\
\cline { 2 - 3 } & \multicolumn{2}{|c|}{$\mathrm{mg} / \mathrm{dm}^{3}$} \\
\hline $\mathrm{B}$ & $5.82 \cdot 10^{-3}-0.49$ & $9.04 \cdot 10^{-2}-0.6$ \\
\hline $\mathrm{Ba}$ & $1.28 \cdot 10^{-3}-15.91$ & $0.14-59.5$ \\
\hline $\mathrm{Ca}$ & $0.23-199.56$ & $2.64-36.97$ \\
\hline $\mathrm{Cs}$ & $1.61 \cdot 10^{-3}-20.79$ & $0.11-54.57$ \\
\hline $\mathrm{K}$ & $3.28-86.65$ & $1.67-13.16$ \\
\hline $\mathrm{Na}$ & $0.84-601.65$ & $16.72-304.63$ \\
\hline $\mathrm{Se}$ & $4.19 \cdot 10^{-2}-40.58$ & - \\
\hline $\mathrm{Sr}$ & $8.8 \cdot 10^{-4}-17.3$ & $0.56-23.45$ \\
\hline $\mathrm{Ag}$ & $1.13 \cdot 10^{-2}-3.04 \cdot 10^{-2}$ & - \\
\hline $\mathrm{Al}$ & $1.52 \cdot 10^{-2}-3.67 \cdot 10^{-2}$ & $3 \cdot 10^{-3}-3.06 \cdot 10^{-2}$ \\
\hline $\mathrm{As}$ & $5.52 \cdot 10^{-3}-1.1$ & - \\
\hline $\mathrm{Cd}$ & $7.7 \cdot 10^{-3}-1.2 \cdot 10^{-2}$ & $1.94 \cdot 10^{-4}-3.64 \cdot 10^{-3}$ \\
\hline $\mathrm{S}$ & $1.29-120.36$ & - \\
\hline $\mathrm{Li}$ & - & $5.66 \cdot 10^{-5}-0.6$ \\
\hline $\mathrm{Mg}$ & - & $0.93-3.39$ \\
\hline $\mathrm{Co}$ & - & $6.16 \cdot 10^{-4}-3.01 \cdot 10^{-3}$ \\
\hline $\mathrm{Fe}$ & - & $5.27 \cdot 10^{-3}-1.34$ \\
\hline $\mathrm{Ti}$ & - & $5.97 \cdot 10^{-5}-3.66 \cdot 10^{-4}$ \\
\hline $\mathrm{U}$ & - & $1.69 \cdot 10^{-3}-1.93 \cdot 10^{-2}$ \\
\hline $\mathrm{Zn}$ & - & $6.79 \cdot 10^{-4}-2.02 \cdot 10^{-2}$ \\
\hline
\end{tabular}

The chemical composition of post-operation liquids depends not only on the composition of the fracturing fluid (which is selected individually for a given borehole), but also on the rock mass into which it is injected. It can be characterized with significant variability in respect of both the quality and quantity. Differences exist both in case of different areas of Poland (in which boreholes were drilled) and also among different portions of the liquid within the same borehole.

Table 4. Physicochemical characteristics of drilling waste solid phase [13].

\begin{tabular}{|c|c|c|}
\hline Reaction & $\mathrm{pH}$ & $7.49-9.65$ \\
\hline Water content & {$[\%]$} & $4.9-52.1$ \\
\hline $\begin{array}{c}\text { Loss on ignition at } \\
850^{\circ} \mathrm{C}\end{array}$ & {$[\%]$} & $6.5-18.1$ \\
\hline Yield point & {$[\%]$} & $12.08-28.52$ \\
\hline Liquid limit & {$[\%]$} & $18.95-54.69$ \\
\hline Plasticity index & {$[\%]$} & $5.74-26.17$ \\
\hline Filtration coefficient & {$[\%]$} & $2.91 \cdot 10^{-8}-6.24 \cdot 10^{-6}$ \\
\hline
\end{tabular}

The purification of drilling fluids takes place on the area of drilling rig with the use of vibrating, linear and deck sieves, sand separators, gravel sludge, centrifugal separators, hydro-cyclones, flocculation stations. Those treatments enable the reuse of the drilling fluid both for drilling another borehole and for applying as the warp for making a new drilling fluid.

Table 5. Chemical composition of drilling waste solid phase [13].

\begin{tabular}{|c|c|c|}
\hline \multirow{2}{*}{ Ele mental } & Pomeranian Basin & Lublin Basin \\
\cline { 2 - 3 } & \multicolumn{2}{|c|}{$\mathrm{mg} / \mathrm{kg}$ dry weight } \\
\hline $\mathrm{Al}$ & $18370.1-48112.7$ & $25824.7-38418.3$ \\
\hline $\mathrm{Fe}$ & $20811.5-66476.4$ & $33342.7-37149.8$ \\
\hline $\mathrm{Ca}$ & $20209.2-62542.9$ & $42527.4-47479.2$ \\
\hline $\mathrm{Mg}$ & $8432.4-29968.9$ & $17449.8-22697.6$ \\
\hline $\mathrm{Na}$ & $1948.4-44987$ & $2783.6-3067.1$ \\
\hline $\mathrm{K}$ & $6794.4-22247.8$ & $9801.1-16762.7$ \\
\hline $\mathrm{S}$ & $17.3-46180$ & $23830.2-214204$ \\
\hline $\mathrm{P}$ & $473.4-1191.9$ & $851.6-1051.1$ \\
\hline $\mathrm{Mn}$ & $277.4-11447.8$ & $362.6-411.4$ \\
\hline $\mathrm{Ba}$ & $454.7-22836.3$ & $877.2-2516.2$ \\
\hline
\end{tabular}

\subsection{Drill cuttings}

Drill cuttings (output) are crumbled fragments of rocks existing in the geological profile of the hole (clays, sands, loam, sandstones, shales, limestones, marlstones, claystones and dolomites) which are contaminated with remains of the drilling fluid, dissolved salts and heavy metals and - in trace quantities - radioactive elements (such as uranium, thorium and their decay products radium and radon) $[1,4,13]$. The table 4 contains data regarding physicochemical properties of drilling waste solid phase (water content, $\mathrm{pH}$, plastic and liquid limits and others). The table 5 presents the chemical composition, while the table 6 shows the content of organic elements of the waste generated during the exploration for shale gas in the Pomerania and Lublin basin. Doing that research is necessary due to requirements listed in the regulation of the Minister for the Environment 
as of the $20^{\text {th }}$ of June 2013 [16] concerning the characteristics of the drilling waste. The outcome of the research determines the choice of technology for further management of the waste. As it arises from the data placed in the table 5, drill cuttings coming from the Pomeranian Basin contain considerable amounts of the following elements: $\mathrm{Al}, \mathrm{Fe}, \mathrm{Ca}, \mathrm{Mg}, \mathrm{K}$ and $\mathrm{Na}$, whereas drill cuttings from the Lublin Basin additionally have very high content of sulphur.

Table 6. Contents of organic compounds in the tested solid phase samples of drilling wastes from Pomeranian and Lublin Basins [13].

\begin{tabular}{|c|c|c|}
\hline Component & $\begin{array}{c}\text { Pomeranian } \\
\text { Basin }\end{array}$ & Lublin Basin \\
\cline { 2 - 3 } & \multicolumn{2}{|c|}{$\mathrm{mg} / \mathrm{kg}$ dry weight } \\
\hline Hydrocarbons & $213.79-1616.14$ & $541.03-631.72$ \\
\hline Gasoline & $3.25-210.53$ & $8.84-181.85$ \\
\hline Mineral oil & $99.8-1541.38$ & $359.18-622.94$ \\
\hline $\begin{array}{c}\text { Total organic } \\
\text { carbon (TOC) }\end{array}$ & $3058-34241$ & $39325-40650$ \\
\hline $\begin{array}{c}\text { Dissolved organic } \\
\text { carbon (DOC) }\end{array}$ & $1113-7736$ & $7548-10190$ \\
\hline $\begin{array}{c}\text { Phenolic index } \\
\text { (phenols) }\end{array}$ & $<0.5-0.8$ & $1.4-7$ \\
\hline $\begin{array}{c}\text { Chemical oxygen } \\
\text { demand (COD) } \\
\text { (dichromate } \\
\text { method) }\end{array}$ & $7950-89032$ & $108400-110229$ \\
\hline \multicolumn{1}{|c|}{$\begin{array}{l}\text { Surfactants } \\
\text { (anionic) }\end{array}$} & $9.0-64.6$ & 34.30 \\
\hline
\end{tabular}

While analyzing the data placed in the table 6 one should pay attention to the high COD, TOC and DOC indicators occurring in the drill cuttings coming from the Lublin Basin. The drill cuttings can also be characterized with lower content of hydrocarbons in comparison to drill cuttings from the Pomeranian Basin.

\section{Amount of waste produced during exploitation}

In line with regulation of the Minister for the Environment as of the $29^{\text {th }}$ of December 2014 concerning the catalogue of waste (Journal of Laws 2014, item 1923) [17], drilling fluids and waste generated as a result of the exploration for and exploitation of natural gas from unconventional accumulations were classified as:

$010505^{*}$ - oil-containing drilling muds and wastes,

0105 06* - drilling muds and other drilling wastes containing hazardous substances,

010507 - barite-containing drilling muds and wastes other than those mentioned in 010505 and 010506 , 010508 - chloride-containing drilling muds and wastes other than those mentioned in 010505 and 010506 .

The amount of waste generated as the outcome of the exploration for hydrocarbons from unconventional accumulations in the area of Poland in the years 2010-2014 is shown in picture 2 .

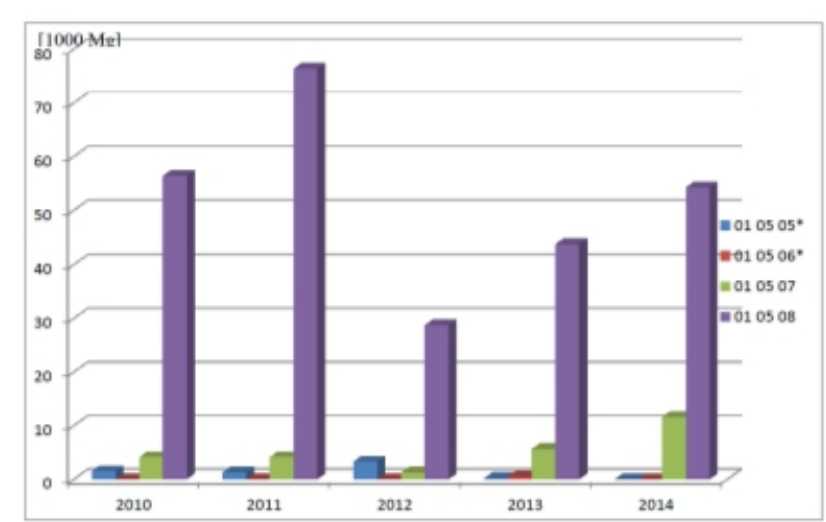

Figure 2. Amount (thousand $\mathrm{Mg}$ ) of produced drilling waste in the years 2010- 2014 in the area of Poland [author's own research based on [18].

Over the last 5 years a total of $292700 \mathrm{Mg}$ of waste from the group 0105 was generated during the exploration for hydrocarbons from unconventional accumulations. The largest part was the waste from the group 010508 (chloride-containing drilling muds and wastes other than those mentioned in 010505 and 010506 ) which comprised 88.62 of all produced waste. The wastes from the group 010507 (barite-containing drilling muds and wastes other than those mentioned in 010505 and 01 05 06) made up for $9.09 \%$ of all waste generated in the analyzed period of time. The hazardous waste from the groups - $010505^{*}$ (oil-containing drilling muds and wastes) and $010506^{*}$ (drilling muds and other drilling wastes containing hazardous substances) - comprised respectively $2.12 \%$ and $0.17 \%$ of all produced waste. The table 7 presents ways of proceeding with the drilling waste.

\section{Directions of management}

Manner of management of the drilling waste resulting from the exploration for natural gas unconventional accumulations depends on physicochemical properties of the waste. The main feature which makes it harder to manage the drilling waste to a considerable extent is the high content of water: from 5 to 53 percent in case of drill cuttings, from 70 to 90 percent in case of used drilling fluid and up to 99.9 in case of flow-back fluid. Another factor is the consistency of the waste- fluid, semifluid and solid. The changeable and hard-to-predict chemical composition of the waste is also an obstacle. In accordance with the article 4.3. of the Act on drilling wastes (Journal of Laws 2008 No 865 item 138) [19] the owner of the drilling waste is obliged in the very first turn to recover it and, if it is not possible due to technological reasons or not justified on economic grounds, to neutralize it in line with the requirements of the environment protection or the program of drilling waste management, considering the best available techniques.

From the data placed in the table 7 it follows that the majority of waste from the group 0105 generated in Poland undergoes the process of recovery: from $71.69 \%$ in 2011 to $96.38 \%$ in the year 2012 . 
Table 7. Amount of waste produced in the years $2010-2014$ in division by subgroups and along with way of managing [author's own research based on [18].

\begin{tabular}{|c|c|c|c|c|c|}
\hline & 2010 & 2011 & 2012 & 2013 & 2014 \\
\hline \multicolumn{6}{|c|}{$010505^{*}$} \\
\hline $\begin{array}{c}\text { Produced } \\
\text { [thousand } \mathrm{Mg} \text { ] }\end{array}$ & 1.5 & 1.2 & 3.3 & 0.2 & - \\
\hline $\begin{array}{c}\text { Recovered } \\
\text { thousand } \mathrm{Mg} \text { ] }\end{array}$ & - & - & 3.3 & 0.2 & - \\
\hline $\begin{array}{c}\text { Neutralized } \\
\text { [thousand } \mathrm{Mg} \text { ] }\end{array}$ & 1.5 & 1.2 & - & - & - \\
\hline \multicolumn{6}{|c|}{$010506^{*}$} \\
\hline $\begin{array}{c}\text { Produced } \\
\text { [thousand } \mathrm{Mg}]\end{array}$ & - & - & - & 0.5 & - \\
\hline $\begin{array}{c}\text { Thermal } \\
\text { treatment } \\
\text { thousand } \mathrm{Mg} \text { ] }\end{array}$ & - & - & - & 0.5 & - \\
\hline \multicolumn{6}{|c|}{010507} \\
\hline $\begin{array}{c}\text { Produced } \\
\text { [thousand } \mathrm{Mg} \text { ] }\end{array}$ & 4.1 & 4.1 & 1.2 & 5.6 & 11.6 \\
\hline $\begin{array}{c}\text { Recovered } \\
\text { [thousand } \mathrm{Mg}]\end{array}$ & 3.3 & 2.6 & - & 4.8 & - \\
\hline $\begin{array}{c}\text { Landfill } \\
\text { [thousand } \mathrm{Mg} \text { ] }\end{array}$ & 0.8 & 1.5 & 1.2 & 0.8 & $1.0^{1}$ \\
\hline \multicolumn{6}{|c|}{010508} \\
\hline $\begin{array}{c}\text { Produced } \\
\text { [thousand } \mathrm{Mg} \text { ] }\end{array}$ & 56.4 & 76.3 & 28.7 & 43.8 & 54.2 \\
\hline $\begin{array}{c}\text { Recovered } \\
\text { [thousand } \mathrm{Mg} \text { ] }\end{array}$ & 47.6 & 55.9 & 28.7 & 39.6 & - \\
\hline $\begin{array}{c}\text { Landfill } \\
\text { [thousand } \mathrm{Mg} \text { ] }\end{array}$ & 8.8 & 20.4 & - & 4.2 & $7.8^{1}$ \\
\hline
\end{tabular}

${ }^{1}$ The data for the year 2014 relate to the waste treated by the producer on their own and cannot be compared to the preceding years due to changes in the legislation.

The common practice connected with the flow-back liquid management is its utilization in the next fracturing. However, it loses gradually its properties due to the increasing salinity and must finally be neutralized. The purification of technological liquid most often consists in removing suspensions, gases and liquid hydrocarbons. Dehydration of liquid drilling waste (used drilling fluids) is performed in transportable chamber filter press in the process of filtration. The process is supported by coagulation. The most frequently used coagulant is the polyaluminium chloride (its overall chemical formula is $\mathrm{Al}_{n}(\mathrm{OH})_{\mathrm{m}} \mathrm{Cl}_{3 \mathrm{n}-\mathrm{m}}$ ). The process of phase separation through filtration in the chamber filter press enables obtaining material which can be characterized with the content of dry matter in a range of 40 to 60 percent and is suitable in this form for use in land reclamation purposes [1].

In the USA the common method is the injection of liquids into reservoirs after exploited conventional accumulations of hydrocarbons or reservoirs of underground saline deposits [8, 20]. In Poland there is only one landfill for waste other than hazardous and neutral. It is situated in the natural gas deposit in Borzecin. In accordance with the concession, waste from the groups 010507 and 010508 can be injected into the rock mass [21].

The hazardous waste from the group $010506^{*}$ generated in Poland have all undergone the process of thermal treatment. The costs of process are high and vary from 3215 to $6440 \mathrm{PLN} / \mathrm{Mg}$ [22].

In case of waste containing hydrocarbons of the type $0105 \quad 05^{*}$ the acceptable methods are incineration and thermal conversion as well as bioremediation (composting, bioreactors, vermiculture and landfarming) [4]. The costs are as follows: up to $4576 \mathrm{PLN} / \mathrm{Mg}$ for waste incineration, and up to $400 \mathrm{PLN} / \mathrm{Mg}$ for bioremediation [22].

One of methods of recycling of drilling waste is solidification (immobilisation) of output. It is most commonly used in case of betonite drilling fluids [1]. The method consists in adding binding materials in a form of Portland cement, gypsum, limestone, fly ashes, blast furnace slag and hydraulic and puzzolans binder [23]. It causes hydraulic binding of soluble compounds (chlorides, heavy metals, petroleum-derived substances). This also increases physicochemical stability and mechanical resistance of the obtained material $[1,23]$. The materials which are the result of the process are then utilized as additions to road surfaces, base layers of roads. They are also used for earthworks and as an addition to building materials [13]. The costs of immobilization depend on applied materials and vary from 108 to 1000 $\mathrm{PLN} / \mathrm{Mg}[22,23]$.

\section{Summary}

Drilling wastes are a basic byproduct arising as a result of the exploration for shale gas. These are mainly used drilling fluids. The waste is of mineral and organic type. Used drilling fluids are colloidal arrangements comprised of fine-dispersing solids (organic and non-organic), polymers and liquids. Both the composition and properties of the waste may change in a wide range depending on geological and technological conditions of the bore and type of applied drilling liquids.

The main purpose of proper management of waste resulting from the process of fracturing should be minimizing its mass. This can be achieved through the effective separation of solid parts from process water. It allows not only to reduce the mass of waste which ends up in the environment, but also to reuse technological fluid therefore protecting water resources and energy needed for their obtention.

The work is financed within the frames of statutory research no 11.11.210.213 at the Faculty of Energy and Fuels.

\section{References}

1. T. Steliga, M. Uliasz, Nafta-Gaz 5 ,273-283 (2012) www.archiwum.inig.pl/INST/nafta-gaz/.../NaftaGaz-2012-05-01.pdf

2. http://infolupki.pgi.gov.pl/sites/default/files/czytelni a pliki/1/02-16-zabiegi.pdf

3. http://infolupki.pgi.gov.pl/sites/default/files/czytelni a pliki/1/02-16 otwory.pdf 
4. J. Macuda, A. Starzycka, Zeszyty Naukowe IGSMiE PAN 85, 259-271 (2013) https://www.minpan.krakow.pl/.../ZN85/21-24-macuda-starzycka.pdf

5. W.T. Stringfellow, J. K. Domen, M. K. Camarillo, W. Sandelin, S. Borglin, J. of Haz. Mat. 275, 37-54, (2014) http://dx.doi.org/10.1016/i.jhazmat.2014.04.040

6. D. Pakuła, Med. Pr. 66(1), 99-117 (2015) http://dx.doi.org/10.13075/mp.5893.00147

7. M. Zoveidavianpoor, A. Gharibi, J. of Nat. Gas Sci. and Eng. 24, 197-209, (2015) http://dx.doi.org/10.1016/j.jngse.2015.03.024

8. L. Torres, O.P. Yadav, E. Khana, Sci. of the Tt1. Env. 539, 478-493, (2016) http://dx.doi.org/10.1016/j.scitotenv.2015.09.030

9. http://www.opppw.pl/en/fracturing fluid compositi on $/ 23$

10. R. D. Vidic, S. L. Brantley, J. M. Vandenbossche, D. Yoxtheimer, J.D. Abad, Science, 340, 826-836, (2013) http://dx.doi.org/10.1126/science.1235009

11. S. L. Brantley, D. Yoxtheimer, S. Arjmand, P. Grieve, R. Vidic, J. Pollak, G. T. Llewellyn, J. Abad, C. Simon, Int. J. of Coal Geo. 126, 140-156(2014) http://dx.doi.org/10.1016/j.coal.2013.12.017

12. PGI-NRI, Environmental impact of hydraulic fracturing treatment performed on Łubień $L E-2 H$ well. Final Report (Warsaw, November 2011). (http://www.pgi.gov.pl/pl/instytut-geologicznyinformacje-prasowe/4091-raport-z-lebieniamateriaprasowe.html).

13. The environmental and shale gas exploration. Results of studies on the soil-water environment, ambient air, acoustic climate, process fluids and wastes.(Directorate General for Environment Protection, Warsaw 2015)

14. D. Zhang, T. Yang, Petrol. Explor. Develop. 42(6), 876-883, (2015) http://dx.doi.org/10.1016/S18763804(15)30085-9

15. W. Orem, C. Tabu, M. Varonka, H. Lerch, A. Bates, M. Engle, L. Crosby, J. McIntosh, Int. J. of Coal Geo. 126,20-31 (2014) doi:10.1016/j.coal.2014.01.003

16. Regulation of the Minister for the Environment as of the $20^{\text {th }}$ June $2013 \mathrm{r}$. concerning the characteristics of drilling waste (Journal of Laws 2013, item 759).

17. Regulation of the Minister for the Environment as of the $9^{\text {th }}$ of December 2014 concerning the catalogue of waste (Journal of Laws 2014, item 1923)

18. Central Statistical Office of Poland, 2016 http://swaid.stat.gov.pl/StanOchronaSrodowiska da shboards/Raporty predefiniowane/RAP DBD SRO D 6.aspx

19. The Act of 10 July 2008 Onmining waste (J. of Laws 2008, item 138, No. 865), as amended (J. of Laws 2013 item 1136 and 2014 item 1101).

20. A. Klimkiewicz, K. Korczak, Research Reports Mining and Env. 3, 43-54, (2012)

21. D. Polak, Min. Res. Manag. 24(3), 275-284 (2008) https://www.minpan.krakow.pl/Wydawnictwa/GSM2433/polak.pdf

22. J. Pyssa, Min. Re. Manag. 24(1), 113-125 (2008) www.min-pan.krakow.pl/ Wydawnictwa/GSM2411/pyssa.pdf
23. J. Pyssa, Przemysł chemiczny 89(7), 927-934 (2010) 